\title{
The view from the back of the Warrior: mobility, privilege and power during the
}

\section{$\underline{\text { international intervention in Bosnia-Herzegovina }^{1}}$}

\author{
Catherine Baker
}

University of Hull

In: Socialist and Post-Socialist Mobilities, ed. Kathy Burrell and Kathrin Horschelmann. Basingstoke: Palgrave Macmillan. (Forthcoming)

This chapter shows how spatial practices of security and intervention, as well as the spatial implications of post-socialism discussed elsewhere in this book, have produced novel mobilities in Bosnia-Herzegovina since the outbreak of war in 1992 and the beginning of international intervention in the same year. Within and around a site of international intervention such as Bosnia-Herzegovina, movement across space is deeply structured by power and privilege. Their structuring effects are all the more visible because of the restrictions placed on movement by the military geographies that emerge from conflict and the political geographies that may develop in response to it: the blocking of transit routes by checkpoints, when they exist; the laying of mines to deny movement to an enemy; the fortification of elements of the built environment, such as schools or factories, that had previously served public purposes; the political division of territory, exacerbated by forced migration; the visa restrictions imposed by powerful states on the country's nationals who may previously not have been subject to them. While some of these factors are also manifested in spaces that are not sites of intervention, it is in (post-)conflict spaces where they are most visible.

\footnotetext{
${ }^{1}$ Earlier versions of this chapter were presented at the EastBordNet conference in Catania in 2011 and as a poster at the RGS-IBG conference in 2010. I am grateful for comments made by the attendees in Catania, the Languages at War research team, and the editors and reviewers of this paper.
} 
The political and social relations that structure movement may be discussed within what John Urry (2007: 44) refers to as a 'mobilities paradigm'. This calls attention to the interdependent movement of bodies, objects, images, messages, and interpersonal virtual communications (Urry 2007: 47). Every mobility has been produced by 'political decision making and ideological meanings', which facilitate or limit the ways in which all these subjects of mobility can move (Adey 2010: 131). As a result, '[w]ho is mobile, and who is not, and how mobility and immobility are managed, ordered and experienced are becoming ever more significant questions' (Burrell 2008: 354). Within the general politics of mobilities, military movement should not be neglected (Kaplan 2006; Gregory 2010; Williams 2011). Humanitarian intervention then produces specific mobilities that warrant closer investigation (Smirl 2008).

The security practices of those who take part in peace operations have a profound effect on constituting and reconstituting space within the area of intervention (Higate and Henry 2009). Whether as deliberate policy or whether as the result of actions consciously taken for other purposes, foreign forces bring certain spaces into being, sustain other kinds of spaces and destroy yet more. The troops and contingents thus 'actively and necessarily create and maintain spaces of security and insecurity', meaning that 'peacekeepers' impact on space is constitutive rather than benign' (Higate and Henry 2009: 17). Higate and Henry's perspective combines this attention to space with an attention to 'the mundane, the routine and the obscure social aspects of security' (2009: 18) that mean security must be viewed as an 'embodied performance' (2009: 17), taking place in space. This position, illustrating the 'embodied' geopolitics demanded by Lorraine Dowler and Joanne Sharp (2001: 167), helps to understand the mobilities of international intervention as they were constituted in BosniaHerzegovina. The chapter explores these by analysing the mobility narratives of people who travelled within Bosnia-Herzegovina as part of the intervention, and particularly the mobility 
narratives of locally-recruited interpreters. After a consideration of the linguistic-material spaces created by military intervention, the chapter goes on to discuss the spatial practices in which interpreters were able to engage as a result of their employment by foreign military forces.

The data used in this chapter consist of semi-structured interviews with foreign soldiers and locally-recruited interpreters collected by the author in 2009-10 as part of a research project on languages in peace operations; some published memoirs of peacekeeping are also drawn on to support the interview data. ${ }^{2}$ The 51 interviewees, recruited through snowball sampling initiated through a number of channels (magazine advertisement; online peacekeeping reunion groups; discussion lists), included 29 locally-recruited interpreters who worked in Bosnia-Herzegovina, 13 British soldiers, 2 British civilian linguists, 2 Danish soldiers, 1 Danish civilian linguist and 4 other civilians with relevant experiences for the project. My positionality as a female civilian British national and native English speaker with fluency in Bosnian/Croatian/Serbian should be acknowledged and will have affected the coconstruction of narrative in every interview. However, an interview-based methodology is appropriate for research of this type because it permits the study of mobilities through "close readings of specific groups from particular historicised places' (Hyndman 2012: 253).

Bosnia-Herzegovina was not only a site of international intervention, but also a space that continued to be affected by the transnational collapse of Communism in 1989-91. ${ }^{3}$ The visa restrictions and refugee management policies imposed by Western governments on citizens of Bosnia-Herzegovina who attempted to travel abroad during and after the war were experienced as so humiliating precisely because of the contrast with what had gone before, when Yugoslavia had been a diplomatically significant state in the Non-Aligned Movement

\footnotetext{
${ }^{2}$ The Bosnia-Herzegovina case study formed part of the Arts and Humanities Research Council-funded project Languages at War: Policies and Practices of Language Contacts in Conflict, which involved the University of Reading, the University of Southampton and the Imperial War Museum.

${ }^{3}$ See also Simić, this volume, on post-socialist mobilities in Serbia.
} 
and when many Yugoslavs had been not just legally but also financially able to travel to most countries with little hindrance. Violence intended to create monoethnic territories forced more than a million Bosnians to move and institutionalized new demarcations based on ethnopolitical separations; however, the geography of where one could find work and where work did not exist had also been determined by the fates of socialist enterprises during the collapse. Indeed, where the war is interpreted as a contest to take over control of and privatize the formerly state-owned enterprises that no longer had formal owners after the collapse of socialism, conflict and post-socialism become utterly intertwined. The intersection of both phenomena - post-socialism and the aftermath of conflict - therefore produced the politics of mobility that this chapter will discuss.

\section{Peace operations and space in Bosnia-Herzegovina}

The United Nations peacekeeping force (UNPROFOR) that served in Bosnia-Herzegovina between August 1992 and December 1995 consisted at its height of some 23,000 troops (Durch 1996: 239) and was developed on the basis of a smaller force sent to Croatia earlier in 1992. The conversion of the intervention to a peace enforcement mission led by NATO rather than the UN resulted in what would now be referred to as a 'surge' of more than 24,000 further troops to form the new Implementation Force (IFOR) in December 1995-January 1996, most notably 20,000 troops from the US military (Phillips 2005: 16). When IFOR became the Stabilization Force (SFOR) a year later, the mission was gradually reduced to 7,000 troops. The expansion of the force's mandate to oversee the implementation of the Dayton Peace Agreement, and the exercise of its power in doing so, had visible effects on space within Bosnia-Herzegovina. Foreign forces had already set up bases in a number of Bosnian towns, particularly in central Bosnia, and had liaison offices and military observer 
missions in others; a military cartography of supply routes, extending over the Bosnian border into Croatia, had already been established. The NATO force divided BosniaHerzegovina into three sectors or Multi-National Divisions (MNDs), each garrisoned by a different subset of the IFOR coalition, and established bases in a greater range of towns. Large, heavy and powerful military equipment was brought into the country, including artillery - which had not been available for use under UNPROFOR's mandate - and construction equipment that would be used by military engineers in repairing damaged infrastructure such as roads and bridges. The force's material presence in space had therefore grown and spread.

Simultaneously, however, its presence in space had a political dimension. The Dayton Agreement obliged all the local armed forces that had taken part in the conflict to remove the checkpoints that had severely impeded civilian movement around Bosnia-Herzegovina and that were now defined as 'illegal roadblocks'; if this was not done on schedule, IFOR would and did close them down by force. IFOR thus contested, and largely won, the practical power to regulate movement within Bosnia-Herzegovina. The right to do so had been granted to the force under the military annex of the Dayton Agreement, which provided that 'IFOR shall have complete and unimpeded freedom of movement by ground, air and water throughout Bosnia and Herzegovina', with the right to 'utilize any areas or facilities to carry out its responsibilities as required for its support, training, and operations, with such advance notice as may be practicable' (OHR 1995). On a wider scale, the political settlement that IFOR was mandated to implement also represented a political reordering of space, based on the division of Bosnia-Herzegovina into entities conceived as Serb and non-Serb, and the subdivision of that non-Serb entity into cantons based on Bosniak majorities, Croat majorities or an official consociational mixture. This settlement has been criticized by scholars including Gearóid Ó 
Tuathail (2006: 145) as an instrument that 'rewarded ethnic cleansing by dividing Bosnia into ethnoterritorial entities which were given state-like administrative powers'.

IFOR thus had the somewhat contradictory task of securing new borders while simultaneously upholding the goal of 'freedom of movement'. 'Freedom of movement', understood as the ability for civilians to move around Bosnia-Herzegovina without being prevented from entering certain territories on the basis of ascribed ethnicity, was a significant objective of IFOR and other agencies including the UN High Commission for Refugees and the High Representative. ${ }^{4}$ The intervention organized a number of initiatives to promote this, including the physical repair of roads and bridges, the introduction of new car registrations that would not associate a vehicle with any particular territory within the country (Hadžić 2007: 142), and the organization of UNHCR convoys with an IFOR escort to deter local residents and police from turning back or even stoning the buses. Facilitating freedom of movement was a prerequisite for achieving the longer-term goal of refugee return (see Ó Tuathail and Dahlman 2006; Jansen 2011). It also ran in parallel with the objective of restructuring Bosnia-Herzegovina's economic life around principles of free trade (Richmond 2008), the same principles that were used to reorder post-socialist European space in general. Spatial practices surrounding this economic policy included the start-up funding of a multiethnic trading area off the highway known as Route Arizona where small-scale producers could sell their goods, and which also became a centre for black-market trade and sex work, catering to - and with some participation from - SFOR members and foreign contractors (Haynes 2010).

The example of the site off Route Arizona, domesticated as 'Arizona Market', demonstrates that the intervention's impact on space was more than material, but rather involved new assemblages of language, materiality and practice. Whenever foreign troops

\footnotetext{
${ }^{4}$ In EU law, the free movement of people, goods, capital and services also constitute the 'four freedoms' that underpin the concept of the Common Market (Barnard 2010).
} 
deploy into a space, they are likely to rename elements of it formally and informally, replacing local understandings of the space with their own naming conventions and historical and symbolic references rather than fully incorporating local names into their own spatial practices: 'Formal and informal military practices of renaming space are ubiquitous, and they exert "the power of naming” perceived by Mary Louise Pratt in colonizers' navigational mapping' (Footitt and Baker 2012: 145; see Pratt 1992: 33). Foreign troops commonly abbreviated or corrupted long Bosnian toponyms with unfamiliar phonetics, but what most permeated into Bosnian geography was the force's practice of naming roads, initiated by UNPROFOR and carried over into the NATO period (IFOR and its successor force, SFOR). UNPROFOR had labelled inter-city roads in English using themes such as geometric shapes, gemstones, birds, snakes and fish; 'Route Arizona', similarly, belonged to a set of highways renamed by IFOR after US states The anthropologist Kimberly Coles, who observed her fellow election monitors making sense of Bosnia-Herzegovina through these maps, remarks that they exemplified foreign interveners living in 'a parallel world of statelike practices and institutions laid out on top of Bosnia proper' because they were insulated from, and often not linguistically or culturally aware of, the country's social complexities (Coles 2007: 64).

These territorial decisions become acts of placemaking, creating new opportunities and constraints in the everyday lives of local people who happen to live within, or choose to move to, these new military spaces (Higate and Henry 2009: 55). Although the presence of militaries at any site creates specific economic, social and cultural geographies (Woodward 2005), the placemaking of deployment represents an accelerated, and often temporary and precarious, version of these processes. The military bases of peacekeeping forces are sources of direct local employment for catering assistants, cleaners, drivers and interpreters (these last are generally highest on the pay scale for local employees). Some contingents, including British forces in Bosnia-Herzegovina from 1998 onwards, may also hire a wider range of 
skilled local workers to replace some combat services support roles such as mechanics, carpenters and financial administrators. The forces pay hard currency, at salary rates higher than those available for comparable or even professional work in the wartime/post-war economy, and unlike a number of local employers in post-war Bosnia-Herzegovina can be reliably expected to pay their employees every month.

The impact of this military-economic placemaking on towns such as Šipovo and Mrkonjić Grad, two small towns in Republika Srpska that became the sites of multiple British bases after 1995, was significant. The major pre-war employers, the factories - formerly constituted as complex 'self-managing enterprises' under the distinctive arrangements of late Yugoslav socialism - had closed, and indeed British forces were renting their premises as bases. The foreignness of the military employer also offered the prospect of employment without the need for 'connections' (veze) that local power-holders in the area might seek to monopolize. ${ }^{5}$ What had been marginal towns in north-west Bosnia thus became temporary economic honeypots when British forces arrived in the region. The same went for Banja Luka, already the largest town in the area but with a parallel significance in the new military geography as the headquarters location of an MND. Banja Luka thus became a key location in the collection of interviews on which this chapter draws.

Among the interpreters I interviewed in and around Banja Luka in 2010 was Dejan, who had been working for successive foreign units in the Banja Luka area since 2001. Dejan had been born in Croatia, a different Yugoslav republic, and his family had moved away from former Yugoslavia in 1993. He narrated his decision to move from the third country in 2000 to Bosnia-Herzegovina, and Banja Luka specifically, as economic:

\footnotetext{
${ }^{5}$ It is possible to conceive of cases where hiring of local employees might not be done with all the transparency there normatively should have been, but at least there would have been the prospect of employment through different 'veze'.
} 
I had a friend here in Banja Luka, and she told me that, well, I knew that the militaries were in, and all sorts of international organizations were here, and I thought that with my English I could come over here and find a job, because I had also heard that the salaries were really good, and I didn't have any job in [the third country] at that time, so I decided to come here to look for a job. ${ }^{6}$

\section{Mobility as the exercise of power}

The performance of security and power through using militarized mobility and denying control over mobility to other forces is evident in many accounts by personnel who participated in the intervention. The memoir of Bob Stewart, the first commander of a British battalion in UNPROFOR, makes clear that military vehicles were employed with the intention to have this performative effect from the start, in this recollection of a conversation with a Canadian battalion commander, Michel Jones:

We talked about how to get the right mix of armoured vehicles. Here Michel was adamant. He advised, 'Noise impresses, size impresses, and numbers impress. I want more of everything. The French armoured personnel carriers are better than mine but they are not as noisy or impressive.' [...] Everything Michel said made great sense to me - particularly about the use of armoured vehicles. (Stewart 1993: 37)

Later commanders continued to recognize this effect. Bob Barry, who commanded another British battalion in Bosnia-Herzegovina during the handover from UNPROFOR to IFOR,

\footnotetext{
${ }^{6}$ Interview, May 2010.
} 
wrote of an incident where IFOR had to enforce a troop withdrawal in accordance with the demilitarization provisions of the Dayton Agreement:

I visit A Company the next day at Kupres. Arriving by helicopter at the British logistic base I can clearly see the Warriors [armoured vehicles] parked up alongside the squadron of tank transporters that will lift them, together with the additional ammunition mounted on DROPS lorries. The company is a formidable sight and is in high spirits. [...]

In Sarajevo Richard Smith confirms that there are indeed several thousand Muslim troops refusing to leave Tito Barracks. The French HQ appears friendly, capable, well organised and deadly serious about evicting the $\mathrm{ABiH}$. They are reinforced by a company of US armoured infantry equipped with Bradley, their equivalent of Warrior, and a company of Apache helicopter gun ships. (Barry 2008: 242)

These impressive, noisy and to certain audiences threatening vehicles did not solely convey soldiers, but often also the interpreters whom soldiers would rely on for language support. Though some local interpreters had desk-based roles, many more spent most of their working hours outside the base travelling to liaison visits or accompanying patrols. Militarized mobility thus became part of their everyday lives, though interpreters' different positionality in terms of localness, civilian status and (often) gender meant that military vehicles figured in their accounts in different ways. One account by Bojan, who worked for British forces in various parts of the MND between 1996 and 2000, conveyed the use of these powerful 
vehicles to perform security and set it in the context of his wider beliefs about the British impact on Banja Luka politics:

[T]he presence of that camp in Ramići [near Banja Luka] meant a lot for the state-making process that happened in Sarajevo. When the British left Banja Luka, that's when these separatist tensions in Banja Luka began to occur. The sheer threat of those armoured vehicles, and some very determined British officers who were there at that time, were the reason that this did not happen earlier, this separatism that is now taking place here, in this town where the two of us have met. $^{7}$

His remark supports Higate and Henry's observation that 'spaces of security can be produced and maintained [in different ways] as a consequence of contrasting security performance noted to flow from a mix of "essentialized" national identity, character and observable practice' (Higate and Henry 2009: 129). Bojan illustrated his perception of the British presence by narrating an incident where a British officer had used a Challenger, the Army's main battle tank, to confront ammunition thieves at a checkpoint near Koprivna on the InterEntity Boundary Line:

Some of the local people were stealing ammunition from a Challenger tank that was parked in front of the checkpoint. And of course it was maybe due to the fact that the officer in command was letting some local people collect some diesel that was dripping from a tank during the summer [...] of course the officer just let them do that, because the diesel was dripping anyway, it would have been lost.

\footnotetext{
${ }^{7}$ Interview, May 2010.
} 
Somebody was, picked up some ammunition. Oh, you should have seen what they did! When this tank, this ninety-ton vehicle, chased the car to Koprivna, turned on the pavement in Koprivna, and ripped it. And pointed the barrel in a café, where this person was hiding. It was (laughs), this was some kind of shock therapy for the ammunition thieves, that never wanted to get near the checkpoint again. [...] But, after that, they had to fix the asphalt of the pavement. It cost something like ten thousand marks for them to get the machines for asphalting. But it was a demonstration of power which was necessary back then. Because if they hadn't done that they would just come again and try to steal the ammunition of the tank. [...] So that was one interesting occasion, when I looked at how quickly the Army is ready to just turn into combat machinery in a second (snaps fingers). When they were completely relaxed, there were just local people who collected diesel, they'd even hired a local man to bake bread and doughnuts and bring them every day. Ah, it was totally relaxed, and suddenly it was just like, woah, on a tank, and chased them. So, it's this shock therapy that I think was very useful back then. ${ }^{8}$

This was a security performance with a flair for the dramatic. The shift from benign paternalism to this almost cartoon-like over-display of power, backed up by what must have appeared like almost unlimited financial resources to make good the damage, made a profound contribution to this narrator's impression of British forces and their differences from other forces that contributed to IFOR/SFOR. The incident could equally have been retold by a different narrator with a more critical voice to portray a foreign force protected by legal and financial privilege as well as the physical power of an Army main battle tank.

\footnotetext{
${ }^{8}$ Interview, May 2010.
} 
Bojan's use of the term 'shock therapy' to describe the officer's performance invites one to reflect on the post-socialist economic reforms across post-socialist Europe, described with the same language, that immediately introduced free trade and privatization after the collapse of Communism, at the cost of increased inflation, unemployment and corruption in public institutions (see Pusca 2007), though to suggest a direct comparison in this speaker's thinking risks academic overstretch.

Departing from the view of mobility and power in the above narrative, however, the most common view of military vehicles in interpreters' narratives was to regard them as a source of danger to oneself. During the conflict, the greatest dangers to interpreters had been from snipers and from local armed forces who might have sought to detain and interrogate them at checkpoints or to coerce them into collaborating with them in their home towns. These dangers subsided after the Dayton Peace Agreements, though some violent confrontations or threats were still reported by interpreters working after 1995. What most worried interpreters - in a context where pre-war healthcare expectations had been badly damaged by war and the conversion to a fragmented health insurance system - was the risk of being injured in a military vehicle accident. This could be the result of a mine strike but could also be the result of poor driving by soldiers. ${ }^{9}$ The drivers most likely to be complained about and to cause danger were young male soldiers in combat regiments who experienced the speed and power of their vehicles as a source of fun and adventure. Interpreters who did not share their excitement but who were in the back of the vehicle without control found it difficult to speak up and protect themselves. In the extract below, Jovana, who worked for British forces between 1998 and 2001, recalls a frightening experience when she could not prevent militarized mobility being enacted on her:

\footnotetext{
${ }^{9}$ Similar complaints have been recorded in multiple intervention sites from local residents interviewed by Béatrice Pouligny (2006: 167-8): "problems of driving on the roads and accidents caused by international staff generally came at the top of the list. People were shocked by some accidents, and still more so by the scant lack of attention paid to them and the lack of respect too often displayed by international staff.'
} 
Once I had a situation that I think I'm going to remember till the rest of my life. It was a big mi[nefield], like sign, 'Minefield,' and I was in the Land Rover, in front of us, so with my team I was in the Land Rover, in front of us was actually a young second lieutenant or whatever, 18-19 years old, just straight from the school. He was a Warrior patrol leader, so he was leading the whole thing. And in the back of that Warrior, apart [from] his team [of] soldiers, was one of my colleagues. And there was a big sign, 'Do not cross,' or, 'Stop, it's a minefield.' But no, he [the lieutenant] decided that the way that he wanted to show his bravery or whatever, and I'm - at that moment I'm just thinking, if they're going to go on, if he stops on a mine - I don't care about him, I just - I do care about my colleague, because he doesn't have a clue what's going on, because he's in the back of the Warrior. And I remember starting screaming to my patrol commander, 'Get Slobodan out of it. I just want him out of it.' Because I don't care about your boss, he's obviously lunatic, you know, he's crazy. But I do care about my colleague, and I was thinking, 'OK, we are behind that Warrior, so if they get stuck on a mine, they're going to go into the air, and we know that we are supposed to come back.' 10

This was one of several such experiences narrated in Jovana's interview. The story, and many others like it, clearly illustrate the significance of embodied performances in constituting security and insecurity. On these drives, mobility and security were understood by the travellers in different, incompatible ways. For soldiers deployed to Bosnia-Herzegovina, especially by the late 1990 s when threat levels to them were low and patrolling had become

${ }^{10}$ Interview, November 2009. 
routine, the deployment had a touristic quality fuelled, off-duty, by cheap food, alcohol, goods and services (Baker 2011a). The subjectivity of these young soldiers (though not necessarily of their commanding officers) included not only the acceptance of thrill and risk but also the perception that, as military travellers who had entered a conflict zone, they ought to be exposed to such. Interpreters were at the mercy of soldiers' handling of the vehicle, and their powerlessness in transit crystallized broader feelings about certain troops' disrespect for them as human beings and as people from Bosnia-Herzegovina or former Yugoslavia. Another extract from Jovana's interview, when she had been involuntarily caught up in a Land Rover race, showed that this mobility was also gendered. It is presented at length in order to illustrate the emotional work of recollection in this instance:

We were deployed in Kozara, which is a mountain next to Banja Luka, kind of quite steep. And [the] soldier was driving around the Land Rover, I was in the back of the Land Rover, two of them. There were like two Land Rovers, they were chasing. And I'm sitting in back of the Land Rover, no seats, because it's old Land Rover, so I'm sitting on the floor, holding myself, because they are chasing, in the mountains, like off-road, they love that, off-road... like driving like crazy, because it's like a boy thing, it's an army thing, it's like a video game. Wow! You know. And... so they have seatbelts, handbrake is not working, and you have uphill things, so, you know.

And I'm in the back, no seatbelt, no seat at all, and the satellite phone box is loose as well in the back. And at some point, because they stopped uphill, and without handbrake, he had to kind of speed up like, you know, within seconds. And they're laughing, they're having fun, and that satellite phone box, orange box, it 
looks like a suitcase, like plastic, hard plastic, hit me in the back, and I, seriously at that moment I thought I'm going to be, you know, that I broke my spine and I'm not going to be able to walk. And at that moment I was like, 'If it was in UK, guys, you would be in jail. First of all this kind of vehicle wouldn't be on the road, not to mention me sitting on the floor not having a seat, not having a seatbelt. Not mentioning the box being loose and flying around.' [...] At that point I said, 'This is not the way how you,' you know. But they had fun. They didn't mean anything wrong, just they did... they had fun, they didn't care. 'Are you complaining, or are you having fun? Ah ha ha ha ha. Are you OK there? Yee hah, yippee, you are, such fun. Are you OK there? Are you still alive?' And you're like in tears, you don't know what to do, because you cannot stop them, and you cannot go out, because you're going to be, you don't know. Maybe they're going to leave, and leave you in the middle of the mountains, and, you know, it's Bosnia, you don't want to stay there. And then you come back, 'OK, all my joints, all my bones, are in place. OK, another day.' [...]

And then [...] I felt it's even worse for the reason that obviously they wouldn't be allowed to do that back home, like in UK, so, OK, let's do whatever we want. Let's play games, just because it's Bosnia. Just because it's like, you know, third world country, so we can do whatever we like, nobody's going to catch us. So we're allowed, it's just a boys' game. ${ }^{11}$

In ethical terms, the interpreter might well be said to have been driven in such a way without her consent: 'Agents have a duty, before crossing the boundaries of others, not only to

${ }^{11}$ Interview, November 2009. 
determine whether the other person is consenting, but also to be accountable for having an awareness of the sorts of circumstances and actions that might prevent that other person from voluntarily consenting' (McGregor 1996: 207). The dangers of being left alone in remote territory with no means of getting home, and of confronting soldiers who could influence superiors to terminate a contract, are clearly just such circumstances. They were exacerbated by the tendency, described by interpreters from various bases and phases, for those soldiers who did not appreciate interpreters as professionals to treat them instead as logistical items (elsewhere in her interview, Jovana had retold a briefing reminding soldiers not to forget their helmets, body armour, satellite phone boxes and interpreters). Disregard for interpreters' humanity in this sense was compounded by the disregard Jovana, and others, perceived some soldiers to have towards Bosnians as a group: in her reconstruction of their sense of privilege, 'it's a third world country, so we can do whatever we like'. A growing critical literature on how the agents of international intervention view the sites to which they are deployed (Duffey 2000; Razack 2004; Whitworth 2005; Pouligny 2006; Rubinstein 2008; Sion 2008; Higate and Henry 2009; Fluri 2011; O’Reilly 2012) suggests, regrettably, that this reconstruction would be accurate for a number of troops. Such thinking may lead not just to accidental violence but also to deliberate violence inflicted by troops who come to consider it legitimate (Razack 2004), and thus needs to be challenged when it appears.

\section{The personal mobility of interpreters}

Beyond participating in and being affected by the spatial practices of foreign soldiers, interpreters also found that their own personal mobility was altered in relation to other Bosnians who were not employed in what Kathleen Jennings (2010: 231) has called the 'peacekeeping economy'. The 'peacekeeping economy' comprises the many direct and 
indirect resource flows that enter local, national, regional, and micro-local economic spaces as a result of the activities of foreign military forces and civilian agencies, and one of these effects is the recruitment of local employees including the group discussed in this chapter, interpreters. The economic benefits of such work - high salaries, hard currency, reliable payment - have already been discussed, but traded against this temporary financial gain was the structural precarity of working on a short-term contract for a unit that might relocate within Bosnia-Herzegovina or even withdraw altogether at any time. Interpreters who had completed all or most of their education before 1992 when the war began had formed expectations about their future careers and the ways in which they would use their skills that, in many cases, would not be fulfilled in the trajectories they turned out to have. In becoming and working as interpreters, they experienced not only post-conflict but also post-socialist dislocations. On one hand, they were coming to terms with a type of flexible working that had not existed in pre-war Yugoslavia, and with the dramatic reduction or even absence of entitlements such as sickness and maternity leave. On the other hand, they were coming to terms with a new working identity that they had not expected to take on, to the extent that the very fact that it existed to be taken on was evidence of what had happened to the society they had lived in. ${ }^{12}$

Working or having worked as an interpreter led both directly and indirectly to privileges in personal mobility. This was most visible and direct during the war, when civilian mobility was restricted not only by shortages of fuel, food and water but also by the many checkpoints that all local armed forces involved in the conflict had placed across roads in order to hold territory and deny entry to enemies. While the existence of organized criminal networks across the ethnicized boundaries shows that these checkpoints were more porous than might normatively be imagined (Andreas 2007), the level of danger involved in presenting oneself

\footnotetext{
${ }^{12}$ The economic aspects of working as an interpreter are discussed in more detail by Baker (2012a) and the ruptures in interpreters' educational trajectories are discussed by Baker (2011b).
} 
at a checkpoint in times where 'enemy' civilians were at risk of detention, imprisonment and torture made them effectively impassable for most. Mobility out of surrounded cities, including the UN Safe Areas (see Hyndman 2003), was thus extremely restricted unless one had the capital to negotiate safe passage. Interpreters working for UNPROFOR, however, were officially able to pass through checkpoints in the course of their duties when they accompanied convoys along routes that UNPROFOR had negotiated in advance with the liaison officers of the relevant local armed forces. This safe conduct did not always materialize: checkpoint guards often attempted to turn back UNPROFOR convoys and sometimes succeeded, making the checkpoint a major site of confrontation between peacekeepers and local militaries. Even when a convoy was allowed through, guards might attempt to reject or even detain the interpreter, whose safety would then depend on an UNPROFOR officer's ability to negotiate and willingness to use force. Lejla, who had worked for UNPROFOR in Sarajevo during this period, recalled two checkpoint confrontations with dramatically different results. In one incident, an UNPROFOR officer who was present when a convoy was stopped at a checkpoint had allowed a different interpreter to be detained; she had been released after two weeks, quit her job and left the country. In another:

I had a similar situation at the checkpoint, but the liaison officer for whom I was working, he said [...] 'She works as an interpreter for UNPROFOR, she has a UN ID card, you can allow us safe passage or not. You cannot take people off our vehicles and cars.' Then we had to stay at this checkpoint for about forty minutes, until all the phone calls were made, and we were ordered to go back. We were not allowed to pass through, and then we had to file a request for a clearance for me 
to go back to Sarajevo with a strong recommendation that in the future we always announce our movements. ${ }^{13}$

Passage through a wartime checkpoint was a high-risk situation for interpreters, but it could bring privileges in the shape of being able to buy food outside siege lines at cheaper prices and then take it home for family, friends and neighbours. An extended network of people could thus benefit from one of their number being an interpreter. With the lifting of sieges at the end of the war, the worst price discrepancies were alleviated, but interpreters still experienced privileged mobility compared to most other civilians when it came to crossing former front lines. In one case where two nearby towns had become monoethnic as a result of ethnic cleansing, an interpreter from the now-Bosniak town of Maglaj working at an IFOR base in the now-Serb town of Doboj became a go-between for Bosniaks displaced from Doboj, who asked him to recover hidden valuables or photograph the remains of their homes. In the longer term, he felt that 'we interpreters were the first ones to break the ice' in terms of routine social travel between the towns, and that through taking their friends to socialize there they had influenced the mobility of others in ways that went well beyond their work. ${ }^{14}$

In the course of work, interpreters might travel not only in militarized ground transport but also by helicopter, the aircraft that has become emblematic of late 20th century military mobilities (see Blackmore 2003; Lisle and Pepper 2005). Helicopters enabled UNPROFOR/NATO forces to bypass the uncertainties of ground transport (mountain roads, floods, snow, potential mines or roadblocks) altogether and were a mode of transport that NATO had aimed to control since the introduction of a no-fly zone over Bosnia-Herzegovina in April 1993. The military annex of the Dayton Agreement stated that '[a]ny flight activities by military fixed-wing or helicopter aircraft within Bosnia and Herzegovina without the

\footnotetext{
${ }^{13}$ Interview, October 2009.

${ }^{14}$ Interview, May 2010.
} 
express permission of the IFOR Commander are subject to military action by the IFOR, including the use of necessary force to ensure compliance' (OHR 1995). Local militaries had to apply to IFOR for permission for helicopter flights, and on several occasions a force would have all its helicopter flights banned for several days as punishment for making an unauthorized flight or obstructing a cargo inspection (Rayner 1996). A senior British officer recalled that helicopter travel had facilitated an emotional visit for an interpreter that he could not have made as a private individual, during a journey in 1998 when a British general offered to fly him back to the village and house in eastern Bosnia that he had been forced to leave:

So we landed in the garden and we went and spoke to the man in the grey shirt, who was the Serb who had taken over the house and was living in it. But it was a very strange, sort of rather emotional moment for this chap to drop in, you know, almost from heaven, as it were, to see where his house was, and the Serb assured him that his mother's grave was being properly looked after and things like that. $[\ldots]$

Q: And if somebody had been a private individual, would they not have been able to get back there?

A: They probably wouldn't have risked getting back there at that stage, it would still have been too hostile for a Muslim to turn up that deep into Republika Srpska. So it was an odd moment to drop in out of the sky. ${ }^{15}$

\footnotetext{
${ }^{15}$ Interview, May 2009.
} 
This was another remarkable performance of security and mobility, using resources so far outside the reach of a Bosnian civilian as to seem an exercise of power 'almost from heaven'. Even the power to arbitrarily deviate en route was reserved, under NATO's control of Bosnian airspace, to the aircraft of the intervention, and would have been cause for the suspension of helicopter privileges if exercised by the aircraft of the local militaries.

Yet working as an interpreter could also mean being expected to be more mobile than one's circumstances permitted. The work pattern of many bases until the early 2000s was for interpreters to complete alternating 12-hour shifts within a duty week or fortnight and then to spend the next week or fortnight off work. During their duty weeks they were accommodated on the base. The shift patterns caused difficulty for women who already had caring responsibilities, and one woman who had worked as an interpreter on these kind of shifts reported driving home at night between shifts in order not to be separated from her baby. When military bases closed down because a unit was being posted elsewhere in BosniaHerzegovina, interpreters would need to move with the unit in order to keep the job. This was sometimes possible for people without family responsibilities, but it would mean redundancy if an interpreter was unable to move. In one case, the commanding officer of a British UNPROFOR battalion had attempted to find new employment for two experienced interpreters who had been made redundant after British forces later left the area. He had used personal connections to recommend one interpreter for a secretarial job in Croatia but regretted that he could do nothing for the other interpreter, whose status as a carer required her to remain in her home town. ${ }^{16}$ To hold on to an interpreting post as long as possible required workers to be a maximally flexible subject. Interpreters' social embeddedness often prevented them from fully exercising such flexibility.

\footnotetext{
${ }^{16}$ Interview, May 2009.
} 


\section{Interpreters and international mobility}

Relatively greater opportunities for international mobility, both temporary and permanent, were another significant privilege of having worked as an interpreter. Bosnians had been severely affected after the outbreak of war by Western states' imposition of visa regimes: in contrast to the largely visa-free travel that Yugoslav citizens had used to enjoy, citizens of Bosnia-Herzegovina required visas to travel to the EU's Schengen Area until 2010 and still require them to visit the UK. This was a stark, humiliating contrast to the famous 'red passport' of socialist Yugoslavia, which in Bosnians' narratives of mobility had come to signify not only easier travel but also everything else that had been lost with the destruction of the former country (Jansen 2009). Collectivized as a group that was considered to be at risk of overstaying legal visit lengths and, in so doing, of becoming a security threat to the host state (see Huysmans and Squire 2009), Bosnians were caught up in the geopolitics of mobility, which in contexts of conflict and disaster appears to accommodate the flow of capital and aid more comfortably than the flow of displaced humans (Hyndman 1997: 149). The flow of aid and intervention itself, however, involves a privileged mobility for interveners. Foreign military and civilian workers travelling to Bosnia-Herzegovina on behalf of the intervention did not need visas, whereas their countries demanded them from visiting Bosnians; they spent varying amounts of time in secured spaces (see Duffield 2010); they generally left when their missions were over. Interpreting jobs enabled Bosnians to improve their positions somewhat in this geopolitics of mobility, but not to acquire the same amount of mobility privilege that foreign visitors took for granted.

A common experience for many interpreters who worked for British forces in the IFOR/SFOR period was to visit the UK and/or Germany for two to three weeks in order to participate in Bosnia-specific field exercises for units undergoing pre-deployment training. In 
these Operational Training Group (OPTAG) exercises, soldiers would visit mock villages on Army training ranges and role-play scenarios that the trainers expected them to encounter at their destination. ${ }^{17}$ Characters from the imaginary local population, as well as the troops' interpreters, were role-played by native speakers of the local language(s), including some interpreters flown in from Bosnia-Herzegovina. Interpreters' narratives of OPTAG 'ran on parallel tracks to the official and British understanding' (Baker 2012b: 144), emphasizing linguistic games with their colleagues during the scenarios and also the touristic and consumer practices they engaged in on the margins of OPTAG. One interpreter, Gordana, reported that a colleague had been disciplined after staying on in Germany to buy a car and drive it back to Bosnia. She herself had encountered more serious consequences after extending a visit to the UK for a week and being listed as missing when she did not return to the base in Bosnia-Herzegovina with her group. She implied that her supervisors had suspected her of entering the UK with the intention of staying on without documents:

Meanwhile, the supervisor called me. I called her from England and I said 'Don't worry, I'll be back in a few days,' which I did, but when I came back I was sacked because I shouldn't have done it. [...]

I didn't mind, because, when I was sacked I was a bit disappointed, as I said, I was a bit angry with myself, as well. I was - I thought I shouldn't have done it. But in the end of the day when I thought about it later I was told by a few people, quite a few people, 'Oh yes, if you stay there shouldn't be any problems,' and - I should have talked with somebody else, probably, but I thought, 'If they know,

\footnotetext{
${ }^{17}$ The villages had been built to simulate German villages in 1942 (Ware 2012: 117) and had been adapted for 'Balkans' training by, for instance, putting up signs in Cyrillic script (to accustom soldiers to the otherness of not being able to read letters off a road sign).
} 
they've been working now for almost ten years, so they should know.' So I stayed, and it raised a big problem. So I guess it's their fault and my fault as well. ${ }^{18}$

Either a lack of policy or a lack of information at the level of Gordana's supervisor had led to this unfortunate result, where her personal circumstances had intersected with British official anxiety about foreigners on tourist visas becoming undocumented immigrants through 'overstaying' 19

Gordana's account also hints at one of the several routes for international mobility that became open to interpreters. This group of young skilled workers, a profile that foreign agencies considered essential for the reconstruction of Bosnia-Herzegovina, 'buil[ $t]$ up language proficiency, social networks and finances' in the course of their work and in fact ended up among the people most able to settle permanently outside the country (Jansen 2006: 193-4). This could be achieved by studying in higher education abroad and taking advantage of post-study work visa schemes where they existed, or by obtaining funds and contacts to enter as a foreign worker. Another route, which to the best of the author's knowledge was taken up only by female interpreters, was marriage to a foreign citizen whom they had met in the course of their work. Although interpreters' work trajectories had granted them advantages for all these routes, it was not the case that every former interpreter who wanted to travel could do so. One interpreter, in conversation, expressed disappointment that UK public spending cuts and tuition fee increases were making it ever harder for former interpreters to study in a country with which they had already established connections. Another, discussing the problems of raising a family in a country where politicians spoke

\footnotetext{
${ }^{18}$ Interview, May 2010.

${ }^{19}$ See Fekete 2009: 19-42 for a critical description of the hardening UK migration policy in the early 2000s, the time when this visit took place. British soldiers who were not UK citizens often experienced similar obstacles to their international mobility during the 2000s (Ware 2012).
} 
only of politics, used restricted international mobility as a symbol of socio-economic problems that Bosnia-Herzegovina's leaders were yet to solve:

But you just have to move on and say, 'OK, that's past, let's move on, let's talk money (laughs). Let's talk development, let's talk a good life, here.' We still you know, we don't have a chance to take our children for a holiday to Paris, to Disneyland, whatever, because it's too expensive, it takes visas, it takes many many things to do so. And having all those problems on one side, how could we think about nationalism and stuff like that ${ }^{20}$

In the contemporary globalized economy of security, the countries of interpreters' former employers were not the only destinations for migration. Private military contractors in charge of logistics in Afghanistan and Iraq recruited workers in catering, construction, firefighting, security and administration to work on multi-national bases in these new conflict zones, requiring 'fluent English' of all applicants. ${ }^{21}$ Former interpreters were at an advantage in this recruitment since they already had proven expertise in military English and satisfactory track records of working in military environments. Though salaries were yet higher, the risks to workers were greater than interpreters in Bosnia-Herzegovina - at least in peacetime - had faced. More than 900 foreign civilian contractors were reported to have been killed in the first four years of the war in Iraq, including one Bosnian carpenter (Brown 2010: 829-30). The dangers were well known to former interpreters who were considering what to do next. Bojan, for instance, described the death of a man from his home town who had been killed when his convoy struck a landmine in Afghanistan:

\footnotetext{
${ }^{20}$ Interview, May 2010.

${ }^{21}$ Advertisement by DynCorp on a Bosnian recruitment website, http://www.posao.ba/job.php?jobID=54919 (accessed 9 May 2011).
} 
[I]t took them 14 days to get that man back [...]. Because of the lack of coordination between the embassies. First of all, embassies don't know that those people are there, because they go through private companies, and they don't go through embassies. You don't need a visa to get there, you just need a passport and a company contract. But when you die and they have to bring you back, it's a complication with embassies, because the embassies don't know who you were. And why did you go there? It took them 14 days to get that man back.! ${ }^{22}$

Although working as a locally-recruited interpreter in Bosnia-Herzegovina gave Bosnians access to resources that could facilitate mobility, the fact that they had been employed by the militaries of foreign countries did not automatically lead to their mobility as an occupational group. No new visa class in SFOR-contributing states, for instance, was created for former local employees of SFOR. Indeed, an automatic right to resettlement for interpreters did not come up for discussion in the West until the late 2000s, when it became evident that interpreters in Iraq and Afghanistan had been targeted as a class for persecution and initiatives such as the US-based 'List Project' were created to lobby coalition governments for interpreter resettlement (see Fitchett 2012). Interpreters from Bosnia-Herzegovina who could satisfy the authorities of a potential host country that they had a well-founded fear of persecution were able to claim asylum on an individual basis. It is clear that some former interpreters took this route as a result of their individual experiences, although, over the duration of the foreign intervention in Bosnia-Herzegovina as a whole, interpreters were not continually exposed to the same level of danger as their more recent counterparts in Iraq and Afghanistan.

\footnotetext{
${ }^{22}$ Interview, May 2010.
} 


\section{Conclusions}

Making sense of mobility, power and privilege in Bosnia-Herzegovina is complicated by the country's simultaneous experience of conflict, reconstruction and intervention on the one hand and post-socialist dislocation on the other. Certain phenomena, notably the ontological crisis in expectations about work and about personal relationships with the state, are common to all post-socialist societies (see Haney 2000; Dunn 2004; Ghodsee 2005; Kideckel 2008). Citizens of many east European countries have experienced the constraints of visa regimes, though some have seen their mobility transform again as their own countries have joined the Schengen Area. Other phenomena are more representative of conflict-affected and postconflict societies, such as the impact of ethnic cleansing and urban siege warfare, or the territorialization of Bosnian space by a military intervention consisting of more than 20,000 troops.

On the face of things, Bosnia-Herzegovina may appear strikingly different from much of post-socialist Europe (Bunce 1999: 770). However, it is possible to argue also that the 'double lens' of analysing post-socialism at the same time as analysing security and conflict is productive for understanding even post-socialist societies that have not been through disruptive war. There, too, security and intervention practices may be observed, and the ways in which they manifest are structured by the circumstances of post-socialism. From Bulgaria, a study of the US military's refurbishment of a hospital near the Serbian border before the Kosovo War confirms, on a small scale, the distancing effect caused by US force protection policies that prevented troops from visiting towns and markets in their leisure time (Valtchinova 2004: 147-9). The disputes around the siting of a US missile base in Rędzikowo, Poland, originate in an attempt on the part of residents and businesses to open this former militarized space (part of a Soviet military training ground in northern Poland) up 
to agriculture and eco-tourism, only to see its airport reconfigured as a new strategic geopolitical node (Materka 2012). The Schengen enterprise is both post-socialist - the incorporation of former Communist space into one liberal European trading area - and security-driven - with unverified migrants from outside its borders perceived as so threatening that high-tech fortified border fences and all-surveying visa screening practices are necessary to keep them excluded (Walters 2002). The mobilities of security and the military can therefore not be detached from the mobilities of post-socialism, whether within the embodied geopolitics of intervention in Bosnia-Herzegovina or further afield. Linking together these military and security geographies within a post-socialist context helps to demonstrate also that the politics of post-socialist mobility are central to understanding the reconfiguration of European political space.

\section{References}

Adey, Peter. 2010. Mobility. London and New York: Routledge.

Andreas, Peter. 2007. Blue Helmets and Black Markets: the Business of Survival in the Siege of Sarajevo. Ithaca, NY: Cornell University Press.

Baker, Catherine. 2011a. 'Have You Ever Been in Bosnia?: British Military Travelers in the Balkans since 1992'. Journeys: International Journal of Travel and Travel Writing 12 (1): 63-92.

Baker, Catherine. 2011b. 'Tito's Children?: Language Learning, Educational Resources and Cultural Capital in the Life Histories of Interpreters Working in Bosnia and Herzegovina'. Südosteuropa 9 (4): 478-502. 
Baker, Catherine. 2012a. 'Prosperity without Security: the Precarity of Interpreters in Postsocialist, Post- Conflict Bosnia-Herzegovina'. Slavic Review 71 (4): 849-72.

Baker, Catherine. 2012b. 'When Bosnia was a Commonwealth Country: British Forces and their Interpreters in Republika Srpska 1995-2007'. History Workshop Journal 74 (1): 131-55. Barnard, Catherine. 2010. The Substantive Law of the EU: the Four Freedoms. Oxford: Oxford University Press.

Barry, Ben. 2008. A Cold War: Front-Line Operations in Bosnia 1995-1996. Stroud: Spellmount.

Blackmore, Tim. 2003. 'Rotor Hearts: the Helicopter as Postmodern War's Pacemaker'. Public Culture 15 (1): 90-102.

Brown, Keith. 2010. 'From the Balkans to Baghdad (Via Baltimore): Labor Migration and the Routes of Empire'. Slavic Review 69 (4): 816-34.

Bunce, Valerie. 1999. ‘The Political Economy of Postsocialism'. Slavic Review 58 (4): 75693.

Burrell, Kathy. 2008. 'Materialising the Border: Spaces of Mobility and Material Culture in Migration from Post-Socialist Poland'. Mobilities 3 (3): 353-73.

Coles, Kimberley. 2007. Democratic Designs: International Intervention and Electoral Practices in Postwar Bosnia-Herzegovina. Ann Arbor, MI: University of Michigan Press. Dowler, Lorraine, and Joanne Sharp. 2001. 'A Feminist Geopolitics?' Space and Polity 5 (3): $165-76$.

Duffey, Tamara. 2000. 'Cultural Issues in Contemporary Peacekeeping'. International Peacekeeping 7 (1): 142-68.

Duffield, Mark. 2010. 'Risk-Management and the Fortified Aid Compound: Everyday Life in Post-Interventionary Society'. Journal of Intervention and Statebuilding 4 (4): 453-74. 
Dunn, Elizabeth C. 2004. Privatizing Poland: Baby Food, Big Business, and the Remaking of Labor. Ithaca, NY: Cornell University Press.

Durch, William C. 1996. UN Peacekeeping, American Politics, and the Uncivil Wars of the 1990s. Basingstoke: Palgrave Macmillan.

Fekete, Liz. 2009. A Suitable Enemy: Racism, Migration and Islamophobia in Europe. London: Pluto.

Fitchett, Linda. 2012. 'The AIIC Project to Help Interpreters in Conflict Areas'. In In Languages and the Military: Alliances, Occupation and Peace-Building, edited by Hilary Footitt and Michael Kelly, 175-85. Basingstoke: Palgrave Macmillan.

Fluri, Jennifer. 2011. 'Armored Peacocks and Proxy Bodies: Gender Geopolitics in Aid/Development Spaces of Afghanistan'. Gender, Place and Culture 18 (4): 519-36. Footitt, Hilary, and Catherine Baker. 2012. 'Fraternization'. In Languages at War: Policies and Practices of Language Contacts in Conflict, ed. Hilary Footitt and Michael Kelly: 13962. Basingstoke: Palgrave Macmillan.

Ghodsee, Kristen. 2005. The Red Riviera: Gender, Tourism, and Postsocialism on the Black Sea. Durham, NC: Duke University Press.

Gregory, Derek. 2010. 'War and Peace'. Transactions of the Institute of British Geographers 35 (2): 154-86.

Hadžić, Lejla. 2007. 'As Dayton Undergoes Proposals for Reform, the Status of Freedom of Movement, Refugee Returns, and War Crimes in Bosnia and Herzegovina'. Human Rights Review 9 (1): 137-51.

Haney, Lynne. 2000. 'Global Discourses of Need: Mythologizing and Pathologizing Welfare in Hungary'. In Global Ethnography: Forces, Connections, and Imagination in a Postmodern World, ed. Michael Burawoy: 48-73. Berkeley: University of California Press. 
Haynes, Dina Francesca. 2010. 'Lessons from Bosnia's Arizona Market: Harm to Women in a Neoliberalized Postconflict Reconstruction Process'. University of Pennsylvania Law Review 158 (6): 1780-829.

Higate, Paul, and Marsha Henry. 2009. Insecure Spaces: Peacekeeping, Power and Performance in Haiti, Kosovo and Liberia. London: Zed.

Huysmans, Jef, and Vicki Squire. 2009. 'Migration and Security'. In The Routledge Handbook of Security Studies, ed. Myriam Dunn Cavelty and Victor Mauer: 169-79. London and New York: Routledge.

Hyndman, Jennifer. 1997. 'Border Crossings'. Antipode 29 (2): 149-76.

Hyndman, Jennifer. 2003. 'Preventative, Palliative, or Punitive? Safe Spaces in BosniaHerzegovina, Somalia, and Sri Lanka'. Journal of Refugee Studies 16 (2): 167-85.

Hyndman, Jennifer. 2012. 'The Geopolitics of Migration and Mobility'. Geopolitics 17 (2): $243-55$.

Jansen, Stef. 2006. 'The Privatisation of Home and Hope: Return, Reforms and the Foreign Intervention in Bosnia-Herzegovina'. Dialectical Anthropology 30: 177-99.

Jansen, Stef. 2009. 'After the Red Passport: Towards an Anthropology of the Everyday Geopolitics of Entrapment in the EU's "Immediate Outside"”. Journal of the Royal Anthropological Institute 15 (4): 815-32.

Jansen, Stef. 2011. 'Refuchess: Locating Bosniac Repatriates After the War in BosniaHerzegovina'. Population, Space and Place 17: 140-52.

Jennings, Kathleen M. 2010. 'Unintended Consequences of Intimacy: Political Economies of Peacekeeping and Sex Tourism'. International Peacekeeping 17 (2): 229-43.

Kaplan, Caren. 2006. 'Mobility and War: the Cosmic View of US “Air Power"'. Environment and Planning A 38 (2): 395-407. 
Kideckel, David A. 2008. Getting By in Postsocialist Romania: Labor, the Body, and Working-Class Culture. Bloomington and Indianapolis: Indiana University Press.

Lisle, Debbie, and Andrew Pepper. 2005. 'The New Face of Global Hollywood: Black Hawk Down and the Politics of Meta-Sovereignty'. Cultural Politics 1 (2): 165-92.

Materka, Edyta. 2012. 'Hybridizing Postsocialist Trajectories: an Investigation into the Biznes of the U.S. Missile Base in Rędzikowo and Urbanization of Villages in Provincial Poland'. Anthropology of East Europe Review 30 (1): 141-83.

McGregor, Joan. 1996. 'Why When She Says No She Doesn't Mean Maybe and Doesn't Mean Yes: a Critical Reconstruction of Consent, Sex, and the Law'. Legal Theory 2: 175208.

O’Reilly, Maria. 2012. ‘Muscular Interventionism’. International Feminist Journal of Politics 14 (4): 529-48.

Ó Tuathail, Gearóid. 2006. 'Geopolitical Discourses: Paddy Ashdown and the Tenth Anniversary of the Dayton Peace Accords'. Geopolitics 11: 141-58.

Ó Tuathail, Gearóid, and Carl Dahlman. 2006. 'Post-Domicide Bosnia and Herzegovina: Homes, Homelands and One Million Returnees'. International Peacekeeping 13 (2): 242-60. OHR. 1995. 'The General Framework Agreement: Annex 1A'. Office of the High Representative, 14 December. http://www.ohr.int/dpa/default.asp?content_id=368 (accessed 26 June 2012).

Phillips, R. Cody. 2005. Bosnia-Herzegovina: the U.S. Army's Role in Peace Enforcement Operations, 1995-2004. CMH Pub 70-97-1. Fort McNair, DC: US Army Center of Military History.

Pouligny, Béatrice. 2006. Peace Operations Seen from Below: UN Missions and Local People. London: Hurst. 
Pratt, Mary Louise. 1992. Imperial Eyes: Travel Writing and Transculturation. London and New York: Routledge.

Pusca, Anca. 2007. 'Shock, Therapy, and Postcommunist Transitions'. Alternatives: Global, Local, Political 32: 341-60.

Rayner, Mark. 1996. 'Transcript of Press Briefing'. IFOR AFSOUTH, 28 February. http://www.nato.int/ifor/trans/t960228a.htm (accessed 27 June 2012).

Razack, Sherene H. 2004. Dark Threats and White Knights: the Somalia Affair, Peacekeeping, and the New Imperialism. Toronto: University of Toronto Press. Richmond, Oliver P. 2008. 'Welfare and the Civil Peace: Poverty with Rights?'. In Whose Peace?: Critical Perspectives on the Political Economy of Peacebuilding, edited by Michael Pugh, Neil Cooper and Mandy Turner: 289-303. Basingstoke: Palgrave Macmillan. Rubinstein, Robert A. 2008. Peacekeeping Under Fire: Culture and Intervention. Boulder, CO: Paradigm.

Sion, Liora. 2008. 'Dutch Peacekeepers and Host Environments in the Balkans: an Ethnographic Perspective'. International Peacekeeping 15 (2): 201-13.

Smirl, Lisa. 2008. 'Building the Other, Constructing Ourselves: Spatial Dimensions of International Humanitarian Response'. International Political Sociology 2: 236-53.

Stewart, Bob. 1993. Broken Lives: a Personal View of the Bosnian Conflict. London: HarperCollins.

Urry, John. 2007. Mobilities. Cambridge: Polity.

Valtchinova, Galia I. 2004. 'Between a Balkan "Home" and the "West": Popular Conceptions of the West in Bulgaria after 1945'. In The Balkans and the West: Constructing the European Other, 1945-2003, ed. Andrew Hammond: 136-52. Aldershot: Ashgate.

Walters, William. 2002. 'Mapping Schengenland: Denaturalizing the Border'. Environment and Planning D: Society and Space 20 (5): 561-80. 
Ware, Vron. 2012. Military Migrants: Fighting for YOUR Country. Basingstoke: Palgrave Macmillan.

Whitworth, Sandra. 2005. 'Militarized Masculinities and the Politics of Peacekeeping: the Canadian Case'. In Critical Security Studies in World Politics, ed. Ken Booth: 89-106.

Boulder, CO: Lynne Rienner.

Williams, Alison J. 2011. 'Enabling Persistent Presence?: Performing the Embodied Geopolitics of the Unmanned Aerial Vehicle Assemblage'. Political Geography 30 (7): 38190.

Woodward, Rachel. 2005. 'From Military Geography to Militarism’s Geographies:

Disciplinary Engagements with the Geographies of Militarism and Military Activities'. Progress in Human Geography 29 (6): 718-40. 